\title{
Lung function in adults following in utero and childhood exposure to arsenic in drinking water: preliminary findings
}

\author{
David C. Dauphiné • Catterina Ferreccio • \\ Sandeep Guntur · Yan Yuan · S. Katharine Hammond • \\ John Balmes · Allan H. Smith · Craig Steinmaus
}

Received: 7 June 2010/ Accepted: 6 October 2010/Published online: 24 October 2010

(c) The Author(s) 2010. This article is published with open access at Springerlink.com

\begin{abstract}
Purpose Evidence suggests that arsenic in drinking water causes non-malignant lung disease, but nearly all data concern exposed adults. The desert city of Antofagasta (population 257,976) in northern Chile had high concentrations of arsenic in drinking water $(>800 \mu \mathrm{g} / \mathrm{l})$ from 1958 until 1970, when a new treatment plant was installed. This scenario, with its large population, distinct period of high exposure, and accurate data on past exposure, is virtually unprecedented in environmental epidemiology. We conducted a pilot study on early-life arsenic exposure and long-term lung function. We present these preliminary findings because of the magnitude of the effects observed.
\end{abstract}

D. C. Dauphiné · Y. Yuan · A. H. Smith · C. Steinmaus ( $\square)$

Arsenic Health Effects Research Program,

School of Public Health, University of California,

50 University Hall, Berkeley, CA 94720-7360, USA

e-mail: craigs@berkeley.edu

C. Ferreccio

Pontificia Universidad Católica de Chile, Santiago, Chile

e-mail: cferrec@med.puc.cl

\section{S. Guntur}

Veterans Affairs Medical Center,

San Francisco, California, USA

D. C. Dauphiné · S. K. Hammond · J. Balmes · A. H. Smith Division of Environmental Health Sciences, School of

Public Health, University of California, Berkeley, USA

\section{J. Balmes}

Division of Occupational and Environmental Medicine,

University of California, San Francisco, USA

C. Steinmaus

Office of Environmental Health Hazard Assessment,

California Environmental Protection Agency, Oakland, USA
Methods We recruited a convenience sample consisting primarily of nursing school employees in Antofagasta and Arica, a city with low drinking water arsenic. Lung function and respiratory symptoms in 32 adults exposed to $>800 \mu \mathrm{g} / \mathrm{l}$ arsenic before age 10 were compared to 65 adults without high early-life exposure.

Results Early-life arsenic exposure was associated with $11.5 \%$ lower forced expiratory volume in $1 \mathrm{~s}\left(\mathrm{FEV}_{1}\right)$ $(P=0.04), 12.2 \%$ lower forced vital capacity (FVC) $(P=0.04)$, and increased breathlessness (prevalence odds ratio $=5.94,95 \%$ confidence interval 1.36-26.0). Exposure-response relationships between early-life arsenic concentration and adult $\mathrm{FEV}_{1}$ and $\mathrm{FVC}$ were also identified $(P$ trend $=0.03)$.

Conclusions Early-life exposure to arsenic in drinking water may have irreversible respiratory effects of a magnitude similar to smoking throughout adulthood. Given the small study size and non-random recruitment methods, further research is needed to confirm these findings.

Keywords Arsenic $\cdot$ Childhood exposure $\cdot$ Drinking water $\cdot$ In utero exposure $\cdot$ Lung $\cdot$ Respiratory

\section{Introduction}

Millions of people worldwide are exposed to arsenic in drinking water (Ravenscroft et al. 2009), an established cause of lung cancer (IARC 2004). Arsenic affects many body tissues, but the human lung seems particularly susceptible (NRC 2001). In fact, lung cancer appears to be the most common cause of death from arsenic in drinking water (Smith et al. 1992; Yuan et al. 2007). Most lung carcinogens-including tobacco smoke, asbestos, and silica-also cause non-malignant respiratory effects. The first 
evidence that ingested arsenic might follow this pattern came from the limited investigations of children in Antofagasta, Chile (Borgoño et al. 1977; Zaldivar 1980). More recently, studies have linked arsenic in drinking water to lung function, cough, breathlessness, crepitations, chronic bronchitis, and bronchiectasis (De et al. 2004; Guha Mazumder et al. 2000, 2005; Guo et al. 2007; Milton and Rahman 2002; Parvez et al. 2008; von Ehrenstein et al. 2005). Most data, however, involve adults with recent exposures. The long-term impacts of early-life arsenic exposures are largely unknown. An ecologic study of northern Chile found increased lung cancer, bronchiectasis, and other chronic obstructive pulmonary disease (COPD) mortality several decades after high in utero and earlychildhood arsenic exposure (Smith et al. 2006). In this paper, we present a pilot study on adult lung function in relation to estimated early-life exposure in the same region using individual-level data.

\section{Materials and methods}

\section{Study area}

Northern Chile is among the driest places on Earth. Nearly everyone there obtains water from municipal supplies, which have arsenic measurements dating back to the 1950s. The absence of alternative water sources means that people's lifetime arsenic exposures can be estimated simply by knowing in which cities they lived. In Antofagasta (population 257,976), drinking water arsenic concentrations were about $90 \mu \mathrm{g} / \mathrm{l}$ until 1958, when arsenic-contaminated rivers were tapped to supply the growing population. Drinking water concentrations averaged $870 \mu \mathrm{g} / \mathrm{l}$ until the world's first large arsenic removal plant became operational in May 1970. From then on, concentrations remained below $150 \mu \mathrm{g} / \mathrm{l}$ with few exceptions. Current levels are around $10 \mu \mathrm{g} / \mathrm{l}$, the World Health Organization guideline (WHO 2004). This unusual exposure scenario created a population of tens of thousands of people exposed to high levels of arsenic in utero or as young children but not as adults. By contrast, the nearby city of Arica (population 193,788) has always had drinking water arsenic levels around $10 \mu \mathrm{g} / \mathrm{l}$. Other cities in northern Chile had variable arsenic levels, but none approached those of Antofagasta (Ferreccio et al. 2000).

Study design and participants

In this pilot study, we compared lung function and prevalence of respiratory symptoms in adults with and without high early-life arsenic exposures. The exposed population comprised long-term residents of Antofagasta, while the unexposed comparison group comprised mostly long-term residents of Arica. A convenience sample was recruited by 2 local nurse-interviewers in each city, who invited employees at the major nursing schools (Universidad Tarapacá de Arica and Universidad de Antofagasta) through personal communication and fliers posted on campus. Interviews and lung function tests were conducted from August 11-21, 2008, in a classroom on campus for 3 days in each city. In total, we enrolled 97 subjects, primarily administrative staff, custodians, and facility workers. Participants were 32-65 years old, such that they would have been young children or in utero during the high exposure period in Antofagasta. The study protocol was approved by the institutional review boards of the University of California, Berkeley, and the Pontificia Universidad Católica de Chile. All subjects gave written informed consent before participating.

\section{Interviews}

Each participant was administered a structured questionnaire to assess lifetime residential and occupational history (all jobs or residences occupied $\geq 6$ months), water source types (municipal tap water, bottled, other), current medications, and medical history. Smoking histories included ages started and quit, years smoked, and average cigarettes smoked per day. Ever smoking regularly was defined as smoking cigarettes at least once per week for $\geq 1$ year, or 20 packs lifetime. Secondhand smoke was defined as someone smoking regularly in the same room at home or at work. Indoor air pollution was defined as irritating or visible smoke, vapors, gases, or dust regularly in the same room. Subjects were also asked about the types of fuels used at home. Occupational exposure was defined as ever being exposed regularly to vapors, dust, gas, or fumes at a job held for $\geq 6$ months (Blanc et al. 2005). Standardized questions were adapted to local Spanish from questionnaires used by the Latin American Project for the Investigation of Obstructive Lung Diseases (PLATINO), the third U.S. National Health and Nutrition Examination Survey (NHANES III), and the second European Community Respiratory Health Survey (ECRHS II).

Questions about respiratory symptoms were adapted from the British Medical Research Council (Cotes 1987). Participants were asked, "Do you often cough when you don't have a cold, such as in the mornings in winter?" Chronic cough was assessed with the follow-up question, "Do you cough like this for at least 3 months a year?" The same questions were asked for phlegm. Subjects were also asked whether they had trouble breathing (1) rarely, (2) often, or (3) always. Finally, participants were asked whether they became breathless when (1) hurrying on level ground or walking up a slight hill, (2) walking with other 
people of the same age on level ground, or (3) if they had to stop for breath when walking on level ground at one's own pace.

\section{Lung function measurement using spirometry}

After height and weight were measured by nurse-interviewers, lung function was assessed according to American Thoracic Society guidelines (ATS 1995) using an EasyOne spirometer (NDD Medical Technologies, Zurich, Switzerland) in diagnostic mode. The same trained technician used the same spirometer in Antofagasta and Arica. Subjects were instructed to take as deep a breath as possible and then blow as hard and long as possible into the spirometer. Following a demonstration and practice with the mouthpiece, they performed tests in a sitting position with active coaching. The main lung function values assessed were forced expiratory volume in $1 \mathrm{~s}\left(\mathrm{FEV}_{1}\right)$ and forced vital capacity (FVC). The maneuver was repeated until the EasyOne indicated satisfactory results were achieved (e.g., $\mathrm{FEV}_{1}$ and $\mathrm{FVC}$ within $200 \mathrm{ml}$ of previous values) or the participant chose to stop. Each subject's best trial (largest sum of $\mathrm{FEV}_{1}$ and FVC) was included in analyses. Spirometry data were reviewed by a pulmonologist (JB).

\section{Arsenic exposure assessment}

Municipal drinking water records used in previous studies (Ferreccio et al. 2000; Smith et al. 2006) were linked with each participant's residential history to obtain age-specific estimates of arsenic exposure. The drinking water database included over 15,000 arsenic measurements in Antofagasta and 11 other cities in northern Chile between 1962 and 1990, when concentrations transitioned from high to low. In initial analyses, high exposure in early life was defined as drinking water containing $>800 \mu \mathrm{g} / \mathrm{l}$ arsenic before age 10 . The unexposed group included mostly long-term residents of Arica. In our main analyses, the unexposed group also included eight subjects who either moved to Antofagasta (from lower exposure areas) after age 10 or who lived in Antofagasta but were over age 10 during the high exposure period. Sensitivity analyses were conducted to evaluate whether changing cut-offs defining "high exposure" (e.g., 800,200 , or $50 \mu \mathrm{g} / \mathrm{l}$ ) and "early-life" (e.g., in utero, 10, or 18 years old) had any impact on results. Exposure-response was assessed both by using early-life arsenic concentration as a continuous variable in models and by stratifying subjects into low, medium, and high exposure categories.

Statistical methods

We analyzed data using SAS 9.2 (SAS Institute Inc., Cary, $\mathrm{NC)}$. Student's $t$-tests were used to compare the means of continuous variables. We conducted one-tailed tests of significance for pulmonary outcomes because of the clear direction of a priori hypotheses regarding arsenic. Otherwise, two-tailed tests were used. Lung function mean residuals (observed values minus age-, sex-, and height-predicted values) and percentages (observed values divided by predicted values) were calculated for subjects with and without high early-life arsenic exposure. Predicted values for northern Chile were not available, so we used those of Mexican Americans in NHANES III (Hankinson et al. 1999). These are within 3\% of reference values obtained from the PLATINO study of 5 large Latin American cities (Perez-Padilla et al. 2006). The choice of reference was not critical because our purpose was to compare arsenic exposed and unexposed, for whom the same reference values were used.

Both univariate and multivariate models were performed. We did not enter age, sex, or height in the multivariate models of lung function because "unadjusted" values were residuals and percentages of age-, sex-, and height-predicted values. Final linear models adjusted for ever regularly smoking and variables that were both (1) associated with pulmonary function in other studies and (2) different between the arsenic-exposed and arsenic-unexposed groups in this study (Table 1). These were entered dichotomously: childhood secondhand tobacco smoke (Moshammer et al. 2006); wood, charcoal, or kerosene fuel use in childhood home (Fullerton et al. 2008); occupational air pollution (Blanc et al. 2009); and university graduation, as an indicator of socioeconomic status (Prescott and Vestbo 1999). Adjusted differences between arsenicexposed and arsenic-unexposed subjects were similar (within $2 \%$ predicted $\mathrm{FEV}_{1}$ ) when potential confounders were entered as continuous variables (e.g., cigarettes per day, age started smoking) or multiple indicator variables (e.g., for education: (1) graduating high school, (2) some post-high school, (3) graduating university). Adjusting for outdoor air pollution, adult secondhand smoke, prior diagnosis of respiratory illness including pulmonary tuberculosis, obesity (BMI $>30 \mathrm{~kg} / \mathrm{m}^{2}$ ) at time of interview, number of spirometry maneuvers attempted, or having reproducible spirometry (difference between highest $2 \mathrm{FEV}_{1}$ and FVC values $\leq 200 \mathrm{ml}$ ) likewise had little impact on results. Prevalence odds ratios (PORs) for respiratory symptoms were calculated using the Wald method of logistic regression. Adjusted models included the same variables used for spirometry outcomes, plus age (in years) and sex.

\section{Results}

As expected, participants reported nearly exclusive use of municipal sources in this desert region. Of the 32 subjects exposed to $>800 \mu \mathrm{g} / \mathrm{l}$ arsenic in drinking water before age 
Table 1 Characteristics of participants [mean \pm SD or $n(\%)$ ]

$B M I$ body mass index

${ }^{\text {a }}$ Reported for jobs held $\geq 6$ months

b Reported "irritating or visible smoke, vapors, gases, or dust regularly in same room"

c Reported someone smoking regularly in same room

d Average per day during period of regular smoking

e Never smokers counted as zeroes

${ }^{\mathrm{f}}$ One subject reported both asthma and tuberculosis

g Rated by EasyOne spirometer from 0 (no acceptable tests) to 5 ( $\geq 3$ acceptable tests and

difference between highest 2

forced expiratory volume in $1 \mathrm{~s}$

$\left(\mathrm{FEV}_{1}\right)$ and forced vital capacity

(FVC) values $\leq 150 \mathrm{ml}$ )

${ }^{\mathrm{h}}$ Difference between highest 2

$\mathrm{FEV}_{1}$ and $\mathrm{FVC}$ values $\leq 200 \mathrm{ml}$

\begin{tabular}{|c|c|c|c|}
\hline & \multicolumn{2}{|c|}{ Peak arsenic before age 10} & \multirow[t]{2}{*}{$P$ value } \\
\hline & $\begin{array}{l}0-250 \mu \mathrm{g} / \mathrm{l} \\
(n=65)\end{array}$ & $\begin{array}{l}>800 \mu \mathrm{g} / 1 \\
(n=32)\end{array}$ & \\
\hline Female & $45(69 \%)$ & $18(56 \%)$ & 0.21 \\
\hline Age in years & $48.9 \pm 9.7$ & $48.0 \pm 6.2$ & 0.62 \\
\hline Height in centimeters & $161.1 \pm 8.6$ & $162.3 \pm 8.7$ & 0.54 \\
\hline Weight in kilograms & $72.2 \pm 13.7$ & $72.6 \pm 15.6$ & 0.90 \\
\hline Obese $\left(\mathrm{BMI} \geq 30 \mathrm{~kg} / \mathrm{m}^{2}\right)$ & $18(28 \%)$ & $6(19 \%)$ & 0.34 \\
\hline \multicolumn{4}{|l|}{ Highest education completed } \\
\hline Less than high school & $9(14 \%)$ & $5(16 \%)$ & 0.89 \\
\hline High school & $12(19 \%)$ & $8(25 \%)$ & 0.53 \\
\hline Technical school or incomplete university & $20(31 \%)$ & $17(53 \%)$ & 0.05 \\
\hline Graduated from university & $21(32 \%)$ & $2(6 \%)$ & 0.003 \\
\hline Data missing & $3(5 \%)$ & $0(0 \%)$ & 0.22 \\
\hline Occupational vapors, dust, gas, or fumes ${ }^{\mathrm{a}}$ & $27(42 \%)$ & $5(16 \%)$ & 0.01 \\
\hline \multicolumn{4}{|l|}{ Indoor air pollution reported ${ }^{\mathrm{b}}$} \\
\hline Ever & $13(20 \%)$ & $3(9 \%)$ & 0.18 \\
\hline Before age ten & $9(14 \%)$ & $3(9 \%)$ & 0.53 \\
\hline Wood, charcoal, or kerosene in childhood home & $41(63 \%)$ & $12(38 \%)$ & 0.01 \\
\hline \multicolumn{4}{|l|}{ Secondhand smoke exposure ${ }^{\mathrm{c}}$} \\
\hline Ever & $35(54 \%)$ & $16(50 \%)$ & 0.60 \\
\hline Currently & $13(20 \%)$ & $3(9 \%)$ & 0.15 \\
\hline Before age ten & $11(17 \%)$ & $12(38 \%)$ & 0.02 \\
\hline \multicolumn{4}{|l|}{ Smoking } \\
\hline Ever & $40(62 \%)$ & $24(75 \%)$ & 0.19 \\
\hline Currently & $21(32 \%)$ & $11(34 \%)$ & 0.84 \\
\hline Age started & $20.2 \pm 5.2$ & $17.6 \pm 3.7$ & 0.04 \\
\hline Cigarettes per day ever ${ }^{\mathrm{d}, \mathrm{e}}$ & $3.4 \pm 5.4$ & $4.2 \pm 5.1$ & 0.47 \\
\hline Pack-years ${ }^{\mathrm{e}}$ & $4.1 \pm 8.1$ & $4.9 \pm 7.0$ & 0.65 \\
\hline \multicolumn{4}{|l|}{ Respiratory illness diagnosed ever } \\
\hline Any ${ }^{\mathrm{f}}$ & $8(12 \%)$ & $1(3 \%)$ & 0.15 \\
\hline Chronic bronchitis & $0(0 \%)$ & $1(3 \%)$ & 0.16 \\
\hline Asthma & $5(8 \%)$ & $0(0 \%)$ & 0.11 \\
\hline Pulmonary tuberculosis & $4(6 \%)$ & $0(0 \%)$ & 0.15 \\
\hline \multicolumn{4}{|l|}{ Lung function test quality } \\
\hline Score $^{\mathrm{g}}$ & $4.2 \pm 1.1$ & $3.8 \pm 1.2$ & 0.05 \\
\hline Reproducible results $^{\mathrm{h}}$ & $60(92 \%)$ & $28(88 \%)$ & 0.45 \\
\hline
\end{tabular}

reported childhood secondhand smoke (38 vs. 17\%) and fewer of them graduated university (6 vs. $32 \%$ ). On the other hand, they reported less secondhand smoke currently (9 vs. $20 \%$ of unexposed), less occupational exposure to vapors, dusts, gases or fumes (16 vs. $42 \%$ ), and less wood, charcoal, and kerosene fuel exposure before age 10 (38 vs. $63 \%$ ). Adjusting for these and other potential confounders had little impact on associations between arsenic and lung function (Tables 2, 3, 4). No subjects reported a past diagnosis of lung or any other type of cancer.

Table 2 shows lung function mean residuals (observed minus predicted) and percent of age-, sex-, and heightpredicted values. High early-life arsenic exposure was 
Table 2 Lung function residuals (observed minus predicted) and percent of age-, sex-, and height-predicted values (mean \pm SD)

\begin{tabular}{|c|c|c|c|c|c|c|}
\hline \multirow[t]{2}{*}{ All subjects } & \multicolumn{2}{|c|}{ Peak arsenic before age 10} & \multicolumn{2}{|l|}{ Crude } & \multicolumn{2}{|c|}{ Adjusted $^{\mathrm{a}}$} \\
\hline & $0-250 \mu \mathrm{g} / 1(n=65)$ & $>800 \mu \mathrm{g} / \mathrm{l}(n=32)$ & Diff. & $P$ value & Diff. & $P$ value \\
\hline Percent of predicted $\mathrm{FEV}_{1}$ & $96.0 \pm 13.9$ & $88.1 \pm 18.3$ & -7.9 & 0.01 & -8.0 & 0.05 \\
\hline Percent of predicted FVC & $101.9 \pm 15.1$ & $94.7 \pm 15.3$ & -7.2 & 0.02 & -7.9 & 0.05 \\
\hline $\mathrm{FEV}_{1}$ residual $(\mathrm{ml})$ & $-127 \pm 417$ & $-375 \pm 611$ & -248 & 0.01 & -244 & 0.06 \\
\hline FVC residual $(\mathrm{ml})$ & $55 \pm 532$ & $-226 \pm 614$ & -280 & 0.01 & -310 & 0.04 \\
\hline Never smokers & $(n=25)$ & $(n=8)$ & & & & \\
\hline Percent of predicted $\mathrm{FEV}_{1}$ & $97.7 \pm 14.3$ & $90.7 \pm 15.1$ & -7.0 & 0.12 & -16.9 & 0.02 \\
\hline Percent of predicted FVC & $104.0 \pm 17.2$ & $93.3 \pm 13.1$ & -10.7 & 0.06 & -19.7 & 0.03 \\
\hline $\mathrm{FEV}_{1}$ residual $(\mathrm{ml})$ & $-77 \pm 406$ & $-257 \pm 414$ & -180 & 0.14 & -496 & 0.02 \\
\hline FVC residual $(\mathrm{ml})$ & $129 \pm 603$ & $-229 \pm 427$ & -359 & 0.07 & -716 & 0.03 \\
\hline Ever smokers & $(n=40)$ & $(n=24)$ & & & & \\
\hline Percent of predicted $\mathrm{FEV}_{1}$ & $95.0 \pm 13.7$ & $87.3 \pm 19.5$ & -7.7 & 0.03 & -4.7 & 0.22 \\
\hline Percent of predicted FVC & $100.6 \pm 13.7$ & $95.2 \pm 16.2$ & -5.4 & 0.08 & -3.7 & 0.25 \\
\hline $\mathrm{FEV}_{1}$ residual $(\mathrm{ml})$ & $-158 \pm 425$ & $-414 \pm 667$ & -256 & 0.03 & -156 & 0.22 \\
\hline FVC residual (ml) & $8 \pm 484$ & $-225 \pm 672$ & -233 & 0.06 & -180 & 0.20 \\
\hline Women & $(n=45)$ & $(n=18)$ & & & & \\
\hline Percent of predicted $\mathrm{FEV}_{1}$ & $94.6 \pm 12.1$ & $91.8 \pm 15.8$ & -2.8 & 0.22 & -1.7 & 0.37 \\
\hline Percent of predicted FVC & $100.9 \pm 14.9$ & $98.7 \pm 14.8$ & -2.2 & 0.30 & -1.6 & 0.39 \\
\hline $\mathrm{FEV}_{1}$ residual $(\mathrm{ml})$ & $-153 \pm 321$ & $-210 \pm 412$ & -56 & 0.28 & -17 & 0.45 \\
\hline FVC residual $(\mathrm{ml})$ & $11 \pm 480$ & $-35 \pm 472$ & -46 & 0.37 & -27 & 0.44 \\
\hline Men & $(n=20)$ & $(n=14)$ & & & & \\
\hline Percent of predicted $\mathrm{FEV}_{1}$ & $99.3 \pm 17.2$ & $83.5 \pm 20.7$ & -15.8 & 0.01 & -14.2 & 0.12 \\
\hline Percent of predicted FVC & $104.2 \pm 15.6$ & $89.6 \pm 15.0$ & -14.6 & 0.005 & -15.8 & 0.06 \\
\hline $\mathrm{FEV}_{1}$ residual $(\mathrm{ml})$ & $-66 \pm 584$ & $-587 \pm 762$ & -521 & 0.02 & -440 & 0.15 \\
\hline FVC residual (ml) & $153 \pm 636$ & $-472 \pm 700$ & -624 & 0.005 & -673 & 0.07 \\
\hline
\end{tabular}

Diff. difference, $F E V_{1}$ forced expiratory volume in $1 \mathrm{~s}, F V C$ forced vital capacity

${ }^{a}$ Adjusted for smoking, childhood secondhand smoke, wood, charcoal, or kerosene fuel use in childhood home, occupational air pollution, and education

associated with a 244-ml decrease in $\operatorname{FEV}_{1}(P=0.06)$ and a $310-\mathrm{ml}$ decrease in FVC $(P=0.04)$. In terms of percent of predicted values, this was equivalent to $8.0 \%$ lower $\mathrm{FEV}_{1}$ and $7.9 \%$ lower FVC ( $P=0.05$ for both). When analyses were restricted to the 33 subjects who reported never smoking regularly, effect estimates remained high but changed dramatically with adjustment (16.9 and $19.7 \%$ decreases in $\mathrm{FEV}_{1}$ and $\mathrm{FVC}$, respectively; $P<0.05$ for both), suggesting unstable results due to the small number of subjects.

In analyses confined to concurrently assessed Antofagasta residents $(n=45)$, subjects who had either lived elsewhere or were older than 10 during the high exposure period served as the "unexposed" reference $(n=12)$. Effect estimates were similar, but the smaller sample size reduced statistical power $\left(8.4\right.$ and $7.1 \%$ decreases in $\mathrm{FEV}_{1}$ and FVC $(P=0.10$ for both $))$. Results were also similar when different age and arsenic concentration cut-offs were used to define early-life exposure. For example, with earlylife exposure defined as $>200 \mu \mathrm{g} / \mathrm{l}$ arsenic before age 18, adjusted differences in $\mathrm{FEV}_{1}$ and FVC between exposed $(n=45)$ and unexposed $(n=52)$ were $9.5 \%(P=0.02)$ and $11.7 \%(P=0.006)$ (not shown in tables). Lung function deficits were similar (within $2 \%$ predicted) in analyses excluding the 9 participants without reproducible spirometry or the participants with the worst and best lung function (i.e., possible outliers).

Table 3 shows exposure-response relationships between peak arsenic concentration before age 10 and $\mathrm{FEV}_{1}$ and FVC, respectively ( $P$ trend $=0.03$ for both). Participants 
Table 3 Exposure response between early-life arsenic and lung function residuals (observed minus predicted) and percent of age-, sex-, and height-predicted values (mean $\pm \mathrm{SD})$

\begin{tabular}{|c|c|c|c|c|c|c|c|c|c|c|}
\hline & & \multicolumn{7}{|c|}{ Peak arsenic before age 10} & & \\
\hline & & \multicolumn{3}{|c|}{$<50 \mu \mathrm{g} / \mathrm{l}(n=45)$} & \multicolumn{4}{|c|}{$50-250 \mu \mathrm{g} / \mathrm{l}(n=20)$} & \multicolumn{2}{|c|}{$>800 \mu \mathrm{g} / 1(n=32)$} \\
\hline Percent predicted $\mathrm{FEV}_{1}$ & & \multicolumn{3}{|c|}{$98.2 \pm 14.6$} & \multicolumn{3}{|c|}{$91.2 \pm 11.0$} & & \multicolumn{2}{|c|}{$88.1 \pm 18.3$} \\
\hline Percent predicted FVC & & \multicolumn{3}{|c|}{$103.6 \pm 16.7$} & \multicolumn{3}{|c|}{$98.2 \pm 10.0$} & & \multicolumn{2}{|c|}{$94.7 \pm 15.3$} \\
\hline $\mathrm{FEV}_{1}$ residual $(\mathrm{ml})$ & & \multicolumn{3}{|c|}{$-63 \pm 443$} & \multicolumn{3}{|c|}{$-270 \pm 314$} & & \multicolumn{2}{|c|}{$-375 \pm 611$} \\
\hline \multirow[t]{4}{*}{ FVC residual $(\mathrm{ml})$} & & \multicolumn{3}{|c|}{$103 \pm 584$} & \multicolumn{3}{|c|}{$-54 \pm 380$} & & \multicolumn{2}{|c|}{$-226 \pm 614$} \\
\hline & \multicolumn{4}{|c|}{$50-250$ compared to $<50 \mu \mathrm{g} / \mathrm{l}$} & \multicolumn{4}{|c|}{$>800$ compared to $<50 \mu \mathrm{g} / \mathrm{l}$} & \multicolumn{2}{|c|}{$P$ trend $^{\mathrm{b}}$} \\
\hline & \multicolumn{2}{|l|}{ Crude } & \multicolumn{2}{|c|}{ Adjusted $^{\mathrm{a}}$} & \multicolumn{2}{|l|}{ Crude } & \multicolumn{2}{|c|}{ Adjusted $^{\mathrm{a}}$} & \multirow[t]{2}{*}{ Crude } & \multirow[t]{2}{*}{ Adjusted } \\
\hline & Diff. & $P$ value & Diff. & $P$ value & Diff. & $P$ value & Diff. & $P$ value & & \\
\hline Percent predicted $\mathrm{FEV}_{1}$ & -7.0 & 0.03 & -4.6 & 0.18 & -10.0 & 0.005 & -11.5 & 0.04 & 0.005 & 0.03 \\
\hline Percent predicted FVC & -5.3 & 0.10 & -2.7 & 0.32 & -8.8 & 0.01 & -12.2 & 0.04 & 0.008 & 0.03 \\
\hline $\mathrm{FEV}_{1}$ residual $(\mathrm{ml})$ & -208 & 0.03 & -152 & 0.16 & -312 & 0.006 & -335 & 0.06 & 0.005 & 0.03 \\
\hline FVC residual $(\mathrm{ml})$ & -157 & 0.14 & -52 & 0.40 & -329 & 0.01 & -429 & 0.04 & 0.006 & 0.02 \\
\hline
\end{tabular}

Diff. difference, $F E V_{1}$ forced expiratory volume in $1 \mathrm{~s}, F V C$ forced vital capacity

a Adjusted for smoking, childhood secondhand smoke, wood, charcoal, or kerosene fuel use in childhood home, occupational air pollution, and education

b Highest known arsenic concentration before age 10 was entered as a continuous variable in linear models

Table 4 Prevalence odds ratios (PORs) and 95\% confidence intervals (CIs) for respiratory symptoms

\begin{tabular}{|c|c|c|c|c|c|c|c|c|}
\hline & \multicolumn{2}{|c|}{ Peak arsenic before age 10} & \multicolumn{3}{|l|}{ Crude } & \multicolumn{3}{|c|}{ Adjusted $^{\mathrm{a}}$} \\
\hline & $0-250 \mu \mathrm{g} / \mathrm{l}(n=65)$ & $>800 \mu \mathrm{g} / 1(n=32)$ & POR & $95 \% \mathrm{CI}$ & $P$ value & POR & $95 \% \mathrm{CI}$ & $P$ value \\
\hline Chronic cough & $7(11 \%)$ & $5(16 \%)$ & 1.53 & $0.45-5.28$ & 0.26 & 1.30 & $0.22-7.80$ & 0.39 \\
\hline Chronic phlegm & $5(7 \%)$ & $2(6 \%)$ & 0.80 & $0.15-4.37$ & 0.38 & 0.93 & $0.10-9.01$ & 0.48 \\
\hline Chronic bronchitis & $2(3 \%)$ & $1(3 \%)$ & 1.02 & $0.09-11.6$ & 0.49 & N/A & N/A & N/A \\
\hline \multicolumn{9}{|l|}{ Trouble breathing } \\
\hline Rarely & $16(25 \%)$ & $4(13 \%)$ & 0.44 & $0.13-1.44$ & 0.08 & 1.20 & $0.25-5.73$ & 0.41 \\
\hline Often & $2(3 \%)$ & $2(6 \%)$ & 2.10 & $0.28-15.6$ & 0.23 & 1.01 & $0.06-17.2$ & 0.49 \\
\hline \multicolumn{9}{|l|}{ Breathlessness walking } \\
\hline Fast/uphill & $15(23 \%)$ & $13(41 \%)$ & 2.28 & $0.92-5.67$ & 0.04 & 2.53 & $0.68-9.45$ & 0.08 \\
\hline At group pace & $9(14 \%)$ & $12(38 \%)$ & 3.73 & $1.37-10.2$ & 0.004 & 5.94 & $1.36-26.0$ & 0.009 \\
\hline At own pace & $7(11 \%)$ & $10(31 \%)$ & 3.77 & $1.27-11.1$ & 0.006 & 3.89 & $0.90-16.8$ & 0.03 \\
\hline Any respiratory symptom & $20(31 \%)$ & $14(44 \%)$ & 1.75 & $0.73-4.20$ & 0.11 & 2.63 & $0.78-8.92$ & 0.06 \\
\hline
\end{tabular}

N/A not available (adjustment variables missing for 1 "yes" respondent)

${ }^{a}$ Adjusted for age, sex, smoking, childhood secondhand smoke, wood, charcoal, or kerosene fuel use in childhood home, occupational air pollution, and education

were also stratified into 3 groups based on highest early-life arsenic concentration: $<50,50-250$, and $>800 \mu \mathrm{g} / \mathrm{l}$. Subjects exposed to $50-250 \mu \mathrm{g} / \mathrm{l}$ and $>800 \mu \mathrm{g} / \mathrm{l}$ had $4.6 \%$ $(P=0.18)$ and $11.5 \%(P=0.04)$ lower $\mathrm{FEV}_{1}$, respectively, than those exposed to $<50 \mu \mathrm{g} / \mathrm{l}$. A similar pattern was seen for FVC. Effect estimates were similar when 8 subjects exposed to $>800 \mu \mathrm{g} / \mathrm{l}$ only after age 10 were put in the intermediate group or excluded entirely.
Table 4 shows prevalence of respiratory symptoms. Thirty-eight percent of exposed subjects reported breathlessness walking at a group pace compared to $14 \%$ of unexposed $(\mathrm{POR}=5.94,95 \%$ confidence interval $(\mathrm{CI}) 1.36-26.02)$. The POR for reporting any breathlessness was $2.53(95 \% \mathrm{CI}$ 0.68-9.45). There was little evidence of associations with chronic cough, phlegm, chronic bronchitis, or "trouble breathing," although few subjects reported these symptoms. 


\section{Discussion}

The decreases in $\mathrm{FEV}_{1}$ and FVC and the PORs above 1.0 for breathlessness identified in this study suggest that earlylife exposure to arsenic in drinking water affects lung function, and these effects remain many years after cessation of high exposure. Assuming each pack-year smoked is associated with a 7.4-ml decrease in $\mathrm{FEV}_{1}$ (Dockery et al. 1988), the decrease in lung function we observed was similar in magnitude to that of 45 pack-years. To our knowledge, this is the first time a drinking water contaminant has been linked to lung function and respiratory symptoms 4 decades after peak exposure.

The exact mechanisms by which arsenic causes lung disease are unknown, and further research may be needed in this area. However, the biological plausibility that ingested arsenic can cause toxicity to the lungs is supported by a variety of studies. In rabbits, the species most similar to humans in terms of arsenic metabolism (NRC 1999), arsenic has been shown to accumulate in the lung more than other organs except the liver and kidney, which are the primary sites of metabolism and excretion (Bertolero et al. 1981; Marafante et al. 1981). Other animal studies show that the primary metabolite of arsenic, dimethylarsinic acid (DMA), is retained longer in the lungs than in other tissues (Kenyon et al. 2008; Vahter et al. 1984). In humans, ingested arsenic is an established cause of lung cancer (IARC 2004), and several studies have linked it to nonmalignant respiratory effects including respiratory symptoms, pulmonary function, and a 10-fold increase in radiographically confirmed bronchiectasis (De et al. 2004; Guha Mazumder et al. 2000, 2005; Guo et al. 2007; Milton and Rahman 2002; Parvez et al. 2008; Smith et al. 2006; von Ehrenstein et al. 2005). In fact, increases in human lung cancer risk are similar whether arsenic is ingested or inhaled (Smith et al. 2009). This body of research provides evidence that the human lung is particularly susceptible to arsenic in drinking water.

Environmental exposures may be particularly harmful in early life because of rapid organogenesis and differences in children's water intake, metabolism, and detoxification (Landrigan et al. 2004). Arsenic is known to cross the placenta and reach the fetus, and total arsenic levels in umbilical cord blood and maternal blood are similar (Concha et al. 1998b; Hall et al. 2007; Vahter 2009). Several studies have shown that metabolism of arsenic to its less toxic metabolite, DMA, is increased in pregnant women (Vahter 2009). However, a recent study of motherinfant pairs in Bangladesh found that less than half of total arsenic in cord blood was DMA (Hall et al. 2007). Other data suggest that arsenic metabolism may differ between children and adults, but these findings are not entirely consistent (Hall et al. 2009). In a study in a highly exposed region of Argentina, children could not metabolize ingested inorganic arsenic to DMA as well as adults (Concha et al. 1998a). In utero arsenic exposures have been linked to reproductive outcomes including stillbirth (HopenhaynRich et al. 2000; Vahter 2008, 2009; von Ehrenstein et al. 2006) and, in male infants, smaller thymus size and acute respiratory illnesses (Raqib et al. 2009). In mice, in utero drinking water arsenic exposure caused irreversible changes in airway reactivity to methacholine, altered gene and protein expression (Lantz et al. 2009) and, at concentrations $\geq 42,500 \mathrm{ug} / \mathrm{l}$, tumors in the lungs of offspring but not dams (Waalkes et al. 2007). An ecologic study comparing the arsenic-exposed city of Antofagasta to other regions of Chile found that those exposed in early life had higher death rates from lung cancer (standardized mortality ratio $(\mathrm{SMR})=6.1,95 \%$ CI 3.5-9.9), bronchiectasis $(\mathrm{SMR}=$ 46.2, 95\% CI 21.1-87.7), and other COPD (SMR = 7.6, 95\% CI 3.1-15.6) in adulthood (Smith et al. 2006). These studies all support our results linking early-life arsenic ingestion to long-term respiratory effects.

Our results are consistent with the 2 previously published studies of ingested arsenic and lung function in people with probable adult exposures. In a study involving 31 subjects in Bangladesh, urinary arsenic concentration (indicative of current exposure) was inversely associated with percent predicted FEV 1 and FVC (Parvez et al. 2008). In 287 subjects from West Bengal, India, men with arseniccaused skin lesions had 256 and $288 \mathrm{ml}$ lower $\mathrm{FEV}_{1}$ and FVC, respectively, than those without skin lesions or known high arsenic exposures (von Ehrenstein et al. 2005). The $\mathrm{FEV}_{1}$ deficits were much smaller in women $(64 \mathrm{ml})$. We also found much smaller effects in women (17-ml $\mathrm{FEV}_{1}$ reduction versus $440 \mathrm{ml}$ for men). Other studies have reported greater arsenic-associated health effects in men (Marshall et al. 2007; Rahman et al. 2006), perhaps due to sex-related differences in arsenic metabolism, water intake, occupational and other exposures (Hertz-Picciotto et al. 1992; Lindberg et al. 2010; Vahter 2009). The greater effects observed in men in this study were not likely due to interactions with smoking since larger arsenic-associated lung function deficits were seen in never smokers, yet men smoked more than women in terms of the proportion of ever smokers (71\% vs. 63\%), pack-years (5.2 vs. 4.0$)$, and cigarettes per day (4.2 vs. 3.4$)$.

Strengths of our study include the accuracy of data on past arsenic exposure. In other places with widespread exposure, the abundance of private wells and other water sources, coupled with a lack of historical arsenic records, makes studies of long-term health effects much more difficult. By contrast, northern Chile has limited water sources and has arsenic records dating back more than 50 years, providing a unique opportunity to study the long-term impacts of exposure. The main limitation of this study is 
the convenience method of participant recruitment, raising concerns about inference and interpretation of results. Although the problem of arsenic in drinking water in northern Chile has been publicized, most information has been on cancer. Our experience is that very few people in the study cities know about the possible role of arsenic in non-malignant respiratory disease. This suggests that people with respiratory problems in Antofagasta (the exposed city) would not be more likely to participate than people with respiratory problems in Arica (the unexposed city), and differential selection is unlikely to account for the effects we identified. A second weakness of this study is that most exposed and unexposed subjects were not assessed concurrently. However, effect estimates remained similar in analyses confined to those who were.

Confounding due to smoking is unlikely to account for the effects identified in this study for 2 reasons. First, entering smoking information into multivariate models had little impact on the association between arsenic and lung function. Second, to explain the observed 8-12\% decrease in $\mathrm{FEV}_{1}$, virtually all of the arsenic-exposed subjects would have to have smoked, while all unexposed would have to have been never smokers. In actuality, the 2 groups had similar smoking histories, and these Chilean smokers consumed fewer cigarettes per day than their U.S. counterparts (CDC 2005). Although arsenic-exposed subjects had slightly less reproducibility of spirometry, less education, and more childhood secondhand smoke exposure, none of these variables were associated with decreased lung function in this study, and adjusting for them had little effect on results. The arsenic-exposed and arsenic-unexposed cities (Antofagasta and Arica) have historically had similar air pollution, industry (e.g., no large coal-fired power plant nearby), traffic patterns (e.g., 1 major highway), geography (coastal desert), sociodemographics, and dietary patterns (INE 2002). Particulate matter of mass median aerodynamic diameter $\leq 10 \mu \mathrm{m}\left(\mathrm{PM}_{10}\right)$ measurements, available for the past 10 years, are similar both at city centers and across neighborhoods of Antofagasta (mean 40.4, range 29.7-51.9 $\mu \mathrm{g} / \mathrm{m}^{3}$ ) and Arica (mean 40.9, range $\left.32.5-48.6 \mu \mathrm{g} / \mathrm{m}^{3}\right)$. Nitrogen dioxide $\left(\mathrm{NO}_{2}\right)$ levels are low in both cities, with annual averages around 8-12 $\mu \mathrm{g} /$ $\mathrm{m}^{3}$ (CENMA 2008; SETEC 2008). Although some arsenic exposures in this area also occur through air and food, these are minor compared to drinking water (Ferreccio and Sancha 2006). Except for the nearly 100-fold contrast in past arsenic exposure, the 2 cities appear similar in all covariates related to lung function. Although confounding cannot be completely ruled out, it seems unlikely that some unknown confounder could cause the lung function decrements observed in subjects with high early-life arsenic exposures, similar in magnitude to decades of heavy smoking.
Federal and state regulations in the United States mandate protection of susceptible subgroups such as pregnant women and children. Without relevant studies, however, the U.S. Environmental Protection Agency has been unable to incorporate data on the long-term health effects of earlylife exposures into any of its drinking water standards (Landrigan et al. 2004). A lack of epidemiologic data is particularly problematic for addressing environmental exposures such as arsenic, for which there are major differences between humans and laboratory animals in metabolism, co-exposures, and potency (NRC 2001). Several human studies have assessed the impacts of earlylife environmental exposures, but these have typically involved short follow-up periods, small numbers of study subjects, or small effect sizes. For example, dioxins in breast milk were linked to a lower $\mathrm{FEV}_{1} / \mathrm{FVC}$ ratio in Danish children (mean age 8.2 years), but the sample size was only 29 (ten Tusscher et al. 2001). In a meta-analysis involving 53,879 children, parental smoking was linked to respiratory symptoms, but relative risks were generally low (around 1.15) (Pattenden et al. 2006). In a subsample of 22,712 of these children with valid lung function data, maternal smoking during pregnancy was linked to a $1 \%$ decrease in $\mathrm{FEV}_{1}$ and essentially no change in FVC (Moshammer et al. 2006). In a longitudinal study on outdoor air pollution in southern California, the mean difference in $\mathrm{FEV}_{1}$ growth from age 10 to 18 between the most exposed city $\left(\mathrm{PM}_{10}=68 \mu \mathrm{g} / \mathrm{m}^{3}\right)$ and the least exposed city $\left(\mathrm{PM}_{10}=17 \mu \mathrm{g} / \mathrm{m}^{3}\right)$ was $82 \mathrm{ml}$. Similar effects were seen for $\mathrm{PM}_{2.5}, \mathrm{NO}_{2}$, and acid vapor (Gauderman et al. 2004). In the current study, we observed 4-fold larger $\mathrm{FEV}_{1}$ decrements $(335 \mathrm{ml})$ nearly 40 years after high arsenic exposures ended.

\section{Conclusions}

This study provides the first evidence that in utero and childhood exposure to arsenic in drinking water is associated with long-term lung function deficits and shortness of breath in humans. The magnitude of the decrease in both $\mathrm{FEV}_{1}$ and FVC suggests that early-life arsenic exposure could have effects similar to smoking throughout adulthood and greater effects than secondhand smoke or air pollution. Nonetheless, certain potential biases-especially those related to non-random selection of subjects-were not controlled for and cannot be excluded. These results should be confirmed in a larger study with participants who are representative of the source population. A larger study could also investigate the effects of lower exposures as well as effect modification and confounding by factors such as diet, occupational exposures, smoking, and gender. The public health importance lies in the enormous morbidity 
and mortality associated with respiratory effects of this magnitude, the millions of children with high exposures worldwide, and the need to incorporate data on early-life susceptibility into environmental policy.

Acknowledgments We thank the Rodriguez-Pereira family and Sandra Cortes for their support. This study was funded by the Northern California Center for Occupational and Environmental Health, the University of California, Berkeley, Center for Global Public Health, and the U.S. National Institute of Health grants P42ES04705 and R01-ES017463. The authors declare they have no competing financial interests.

Open Access This article is distributed under the terms of the Creative Commons Attribution Noncommercial License which permits any noncommercial use, distribution, and reproduction in any medium, provided the original author(s) and source are credited.

\section{References}

ATS (American Thoracic Society) (1995) Standardization of spirometry, 1994 update. Am J Respir Crit Care Med 152(3):1107-1136

Bertolero F, Marafante E, Rade JE, Pietra R, Sabbioni E (1981) Biotransformation and intracellular binding of arsenic in tissues of rabbits after intraperitoneal administration of 74As labelled arsenite. Toxicology 20(1):35-44

Blanc PD, Eisner MD, Balmes JR, Trupin L, Yelin EH, Katz PP (2005) Exposure to vapors, gas, dust, or fumes: assessment by a single survey item compared to a detailed exposure battery and a job exposure matrix. Am J Ind Med 48(2):110-117

Blanc PD, Iribarren C, Trupin L et al (2009) Occupational exposures and the risk of COPD: dusty trades revisited. Thorax 64(1):6-12

Borgoño JM, Vicent P, Venturino H, Infante A (1977) Arsenic in the drinking water of the city of Antofagasta: epidemiological and clinical study before and after the installation of a treatment plant. Environ Health Perspect 19:103-105

CDC (Centers for Disease Control and Prevention) (2005) http://www.cdc.gov/mmwr/preview/mmwrhtml/mm5444a2.html . Accessed 16 September 2009

CENMA (National Center for the Environment) (2008) http://200.29.22.186/chile/index5.html. Accessed 6 July 2009

Concha G, Nermell B, Vahter MV (1998a) Metabolism of inorganic arsenic in children with chronic high arsenic exposure in northern Argentina. Environ Health Perspect 106:355-359

Concha G, Vogler G, Lezcano D, Nermell B, Vahter M (1998b) Exposure to inorganic arsenic metabolites during early human development. Toxicol Sci 44:185-190

Cotes JE (1987) Medical Research Council Questionnaire on Respiratory Symptoms (1986). Lancet 330(8566):1028-1028

De BK, Majumdar D, Sen S, Guru S, Kundu S (2004) Pulmonary involvement in chronic arsenic poisoning from drinking contaminated ground-water. J Assoc Physicians India 52:395-400

Dockery DW, Speizer FE, Ferris BG, Ware JH, Louis TA, Spiro A (1988) Cumulative and reversible effects of lifetime smoking on simple tests of lung function in adults. Am Rev Respir Dis 137:286-292

Ferreccio C, Sancha AM (2006) Arsenic exposure and its impact on health in Chile. J Health Popul Nutr 24(2):164-175

Ferreccio C, Gonzalez CA, Milosavjlevic V, Marshall G, Sancha AM, Smith AH (2000) Lung cancer and arsenic concentrations in drinking water in Chile. Epidemiology 11(6):673-679
Fullerton DG, Bruce N, Gordon SB (2008) Indoor air pollution from biomass fuel smoke is a major health concern in the developing world. Trans R Soc Trop Med Hyg 102(9):843-851

Gauderman WJ, Avol E, Gilliland F et al (2004) The effect of air pollution on lung development from 10 to 18 years of age. N Engl J Med 351:1057-1067

Guha Mazumder DN, Haque R, Ghosh N et al (2000) Arsenic in drinking water and the prevalence of respiratory effects in West Bengal, India. Int J Epidemiol 29(6):1047-1052

Guha Mazumder DN, Steinmaus C, Bhattacharya P et al (2005) Bronchiectasis in persons with skin lesions resulting from arsenic in drinking water. Epidemiology 16(6):760-765

Guo JX, Hu L, Yand PZ, Tanabe K, Miyatalre M, Chen Y (2007) Chronic arsenic poisoning in drinking water in Inner Mongolia and its associated health effects. J Environ Sci Health A Tox Hazard Subst Environ Eng 42(12):1853-1858

Hall M, Gamble M, Slavkovich V, Liu X, Levy D, Cheng Z, van Geen A, Yunus M, Rahman M, Pilsner JR, Graziano J (2007) Determinants of arsenic metabolism: blood arsenic metabolites, plasma folate, cobalamin, and homocysteine concentrations in maternal-newborn pairs. Environ Health Perspect 115(10):15031509

Hall M, Liu X, Slavkovich V et al (2009) Folate, cobalamin, cysteine, homocysteine, and arsenic metabolism among children in Bangladesh. Environ Health Perspect 117(5):825-831

Hankinson JL, Odencrantz JR, Fedan KB (1999) Spirometric reference values from a sample of the general U.S. population. Am J Respir Crit Care Med 159(1):179-187

Hertz-Picciotto I, Smith AH, Holtzman D, Lipsett M, Alexeeff G (1992) Synergism between occupational arsenic exposure and smoking in the induction of lung cancer. Epidemiology 3:23-31

Hopenhayn-Rich C, Browning SR, Hertz-Picciotto I, Ferreccio C, Peralta C, Gibb H (2000) Chronic arsenic exposure and risk of infant mortality in two areas of Chile. Environ Health Perspect 108:667-673

IARC (International Agency for Research on Cancer) (2004) Some drinking-water disinfectants and contaminants, including arsenic. IARC Monograph 84. IARC, Lyon

INE (Instituto Nacional de Estadisticas) (2002) Resultados Generales Censo. http://www.ine.cl. Accessed 6 July 2009

Kenyon EM, Hughes MF, Adair BM, Highfill JH, Crecelius EA, Clewell HJ, Yager JW (2008) Tissue distribution and urinary excretion of inorganic arsenic and its methylated metabolites in C57BL6 mice following subchronic exposure to arsenate in drinking water. Toxicol Appl Pharmacol 232:448-455

Landrigan PJ, Kimmel CA, Correa A, Eskenazi B (2004) Children's health and the environment: public health issues and challenges for risk assessment. Environ Health Perspect 112:257-265

Lantz RC, Chau B, Sarihan P, Witten ML, Pivniouk VI, Chen GJ (2009) In utero and postnatal exposure to arsenic alters pulmonary structure and function. Toxicol Appl Pharmacol 235(1):105-113

Lindberg AL, Sohel N, Rahman M, Persson LA, Vahter M (2010) Impact of smoking and chewing tobacco on arsenic-induced skin lesions. Environ Health Perspect 118:533-538

Marafante E, Rade J, Sabbioni E, Bertolero F, Foà V (1981) Intracellular interaction and metabolic fate of arsenite in the rabbit. Clin Toxicol 18(11):1335-1341

Marshall G, Ferreccio C, Yuan Y et al (2007) Fifty-year study of lung and bladder cancer mortality in Chile related to arsenic in drinking water. J Natl Cancer Inst 99(12):920-928

Milton AH, Rahman M (2002) Respiratory effects and arsenic contaminated well water in Bangladesh. Int J Environ Health Res 12(2):175-179 
Moshammer HG, Hoek G, Luttmann-Gibson H et al (2006) Parental smoking and lung function in children: an international study. Am J Respir Crit Care Med 173(11):1255-1263

NRC (National Research Council) (1999) Arsenic in drinking water. National Academy Press, Washington

NRC (National Research Council) (2001) Arsenic in drinking water 2001 update. National Academy Press, Washington

Parvez F, Chen Y, Brandt-Rauf PW et al (2008) Nonmalignant respiratory effects of chronic arsenic exposure from drinking water among never-smokers in Bangladesh. Environ Health Perspect 116(2):190-195

Pattenden S, Antova T, Neuberger M et al (2006) Parental smoking and children's respiratory health: independent effects of prenatal and postnatal exposure. Tob Control 15:294-301

Perez-Padilla R, Valdivia G, Munoz A (2006) Spirometric reference values in 5 large Latin American cities for subjects aged 40 years or over. Bronconeumol 42(7):317-325

Prescott E, Vestbo J (1999) Socioeconomic status and chronic obstructive pulmonary disease. Thorax 54:737-741

Rahman M, Vahter M, Sohel N et al (2006) Arsenic exposure and age and sex-specific risk for skin lesions: a population-based casereferent study in Bangladesh. Environ Health Perspect 114(12): $1847-1852$

Raqib R, Ahmed S, Sultana R et al (2009) Effects of in utero arsenic exposure on child immunity and morbidity in rural Bangladesh. Toxicol Lett 185(3):197-202

Ravenscroft P, Brammer H, Richards K (2009) Arsenic pollution: a global synthesis. John Wiley and Sons, Chichester

SETEC (Servicios Tecnológicos Ambientales Ltda.) (2008) http://www.setec.cl/. Accessed 6 July 2009

Smith AH, Hopenhayn-Rich C, Bates MN et al (1992) Cancer risks from arsenic in drinking water. Environ Health Perspect 97:259-267

Smith AH, Marshall G, Yuan Y et al (2006) Increased mortality from lung cancer and bronchiectasis in young adults after exposure to arsenic in utero and in early childhood. Environ Health Perspect 114(8):1293-1296
Smith AH, Ercumen A, Yuan Y, Steinmaus CM (2009) Increased lung cancer risks are similar whether arsenic is ingested or inhaled. J Expo Sci Environ Epidemiol 19(4):343-348

ten Tusscher GW, de Weerdt J, Roos CM et al (2001) Decreased lung function associated with perinatal exposure to Dutch background levels of dioxins. Acta Paediatr 90(11):1292-1298

Vahter M (2008) Health effects of early life exposure to arsenic. Basic Clin Pharmacol Toxicol 102(2):204-211

Vahter M (2009) Effects of arsenic on maternal and fetal health. Annu Rev Nutr 29:381-399

Vahter M, Marafante E, Dencker L (1984) Tissue distribution and retention of 74As-dimethylarsinic acid in mice and rats. Arch Environ Contam Toxicol 13(3):259-264

von Ehrenstein OS, Guha Mazumder DN, Yuan Y, Samanta S, Balmes J, Sil A et al (2005) Decrements in lung function related to arsenic in drinking water in West Bengal, India. Am J Epidemiol 162:533-541

von Ehrenstein OS, Guha Mazumder DN, Hira-Smith M et al (2006) Pregnancy outcomes, infant mortality, and arsenic in drinking water in West Bengal, India. Am J Epidemiol 163(7):662-669

Waalkes MP, Liu J, Diwan BA (2007) Transplacental arsenic carcinogenesis in mice. Toxicol Appl Pharmacol 222(3):271280

WHO (World Health Organization) (2004) Guidelines for drinking water, 3rd edition, Chapter 8: Chemical aspects, p. 186. WHO, Geneva. http://www.who.int/water_sanitation_health/dwq/gdwq3. Accessed 27 May 2010

Yuan Y, Marshall G, Ferreccio C et al (2007) Acute myocardial infarction mortality in comparison with lung and bladder cancer mortality in arsenic-exposed region II of Chile from 1950 to 2000. Am J Epidemiol 166(12):1381-1391

Zaldivar R (1980) A morbid condition involving cardio-vascular, broncho-pulmonary, digestive and neural lesions in children and young adults after dietary arsenic exposure. Zentralbl Bakteriol [B] 170(1-2):744-756 